\title{
Current Research: Discovery and Recovery of a 14th Century Dugout Canoe on the Red River, Caddo Parish, Louisiana
}

Jeffrey S. Girard

Northwestern State University of Louisiana

Charles R. McGimsey

Louisiana Division of Archaeology

Follow this and additional works at: https://scholarworks.sfasu.edu/ita

Part of the American Material Culture Commons, Archaeological Anthropology Commons, Environmental Studies Commons, Other American Studies Commons, Other Arts and Humanities Commons, Other History of Art, Architecture, and Archaeology Commons, and the United States History Commons

Tell us how this article helped you.

This Article is brought to you for free and open access by the Center for Regional Heritage Research at SFA ScholarWorks. It has been accepted for inclusion in Index of Texas Archaeology: Open Access Gray Literature from the Lone Star State by an authorized editor of SFA ScholarWorks. For more information, please contact cdsscholarworks@sfasu.edu. 


\section{Current Research: Discovery and Recovery of a 14th Century Dugout Canoe on the Red River, Caddo Parish, Louisiana \\ Creative Commons License \\ (c) (1) (9)}

This work is licensed under a Creative Commons Attribution-NonCommercial 4.0 International License 


\title{
Current Research:
}

\section{Discovery and Recovery of a 14th Century Dugout Canoe on the Red River, Caddo Parish, Louisiana}

\author{
Jeffrey S. Girard ${ }^{1}$ and Charles R. McGimsey ${ }^{2}$ \\ ${ }^{1}$ Northwestern State University of Louisiana. \\ ${ }^{2}$ Louisiana Division of Archaeology
}

In June 2017, Jenna Bradley and Robert Cornett were boating down the Red River in northern Caddo Parish, Louisiana, when they noticed an unusual log protruding from a sandy bank near the town of Belcher. After realizing that it was a dugout canoe, they contacted the Louisiana Department of Wildlife and Fisheries, and eventually word of the find was transmitted to state archaeologist Chip McGimsey at the Louisiana Division of Archaeology. The following day, Bradley and Cornett led Jeffrey Girard and Jameel Damlouji of the Louisiana Archaeological Society to the site. It was obvious that it was a dugout canoe of comparable size and form to one found in 1983 at the base of a steep cutbank on the east side of a now cut off channel of the Red River approximately $12 \mathrm{~km}$ (7 miles) downstream (Figure 1). At the time, the 1983 canoe was thought to be the largest prehistoric watercraft in the Southeastern United States measuring $9.35 \mathrm{~m}$ (or $30 \mathrm{ft}$. 8 inches) long and 56 $\mathrm{cm}$ (1 ft. 10 inches) in diameter. The newly discovered canoe is a little larger, measuring $10.2 \mathrm{~m}$ long (33.4 ft.) and approximately $60 \mathrm{~cm}(2.0 \mathrm{ft}$.) in diameter. Both boats have similar shapes with step-like seats carved into the ends (Figures 2 and 3), and both probably are made from cypress logs, although the wood of the recent find has not been identified with certainty.

A sample of wood from the recently found canoe was radiometrically dated to $590+30$ B.P., calibrated at 2 sigma to A.D. 1298-1413 (Beta- 467673), within the Middle Caddo period. The boat appears to date earlier than mound construction at the nearby Belcher site (16CD13), but is contemporary with occupation of the Willow Chute locality a few miles downstream on the eastern side of the Red River floodplain. Two radiocarbon dates on the earlier boat suggest it was made much earlier, in the early twelfth century A.D., during the Early Caddo period when the Mounds Plantation site was in use.

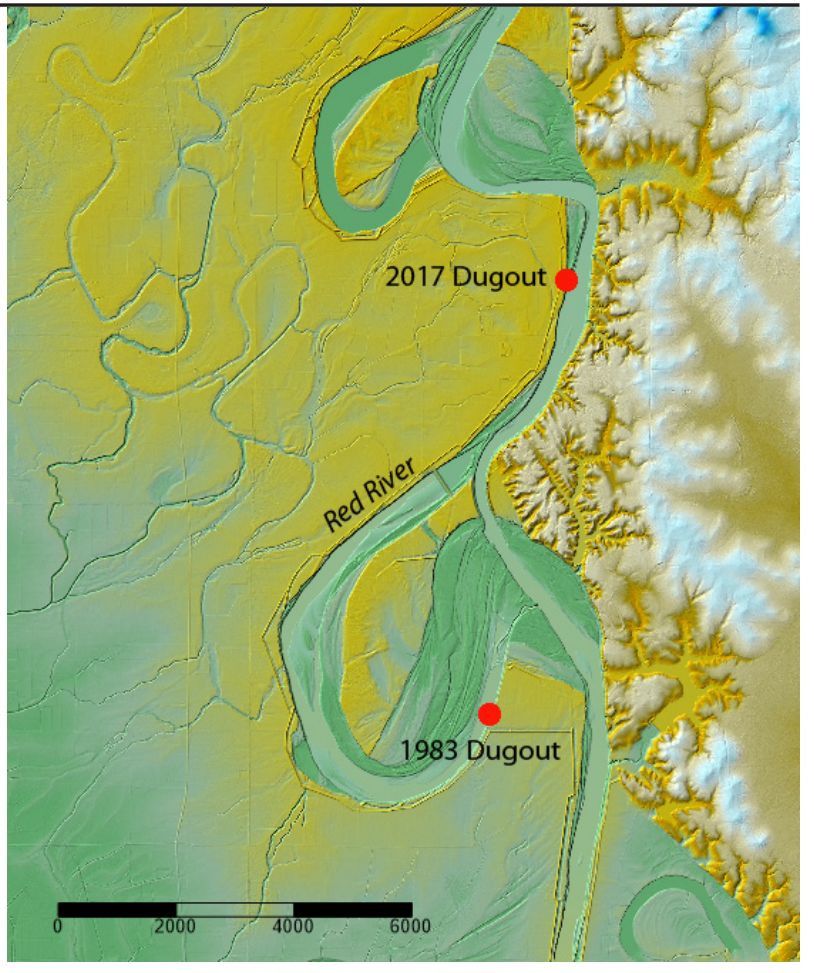

Figure 1. General topographic setting of the 1983 and 2017 dugout canoe sites.

The physical context of the two boats differed significantly. The 1983 boat was found embedded in clay deposits at the base of a nearly vertical bank, probably resting on a deeply buried surface. Removal necessitated burrowing into the bank and cutting the canoe into three sections for transport. The newly discovered boat rested on about a 30 degree slope in shallow, sandy deposits. It is possible that it had been displaced from upstream, perhaps as recently as the spring of 2016 when the region experienced massive floods, as it is unlikely that it would have preserved for several centuries in this context.

Because it was situated on the bank, above the normal water level of the river, it belonged to the Kavanaugh LLC and McKneely Family Partnership, landowners of the adjacent property. The families 


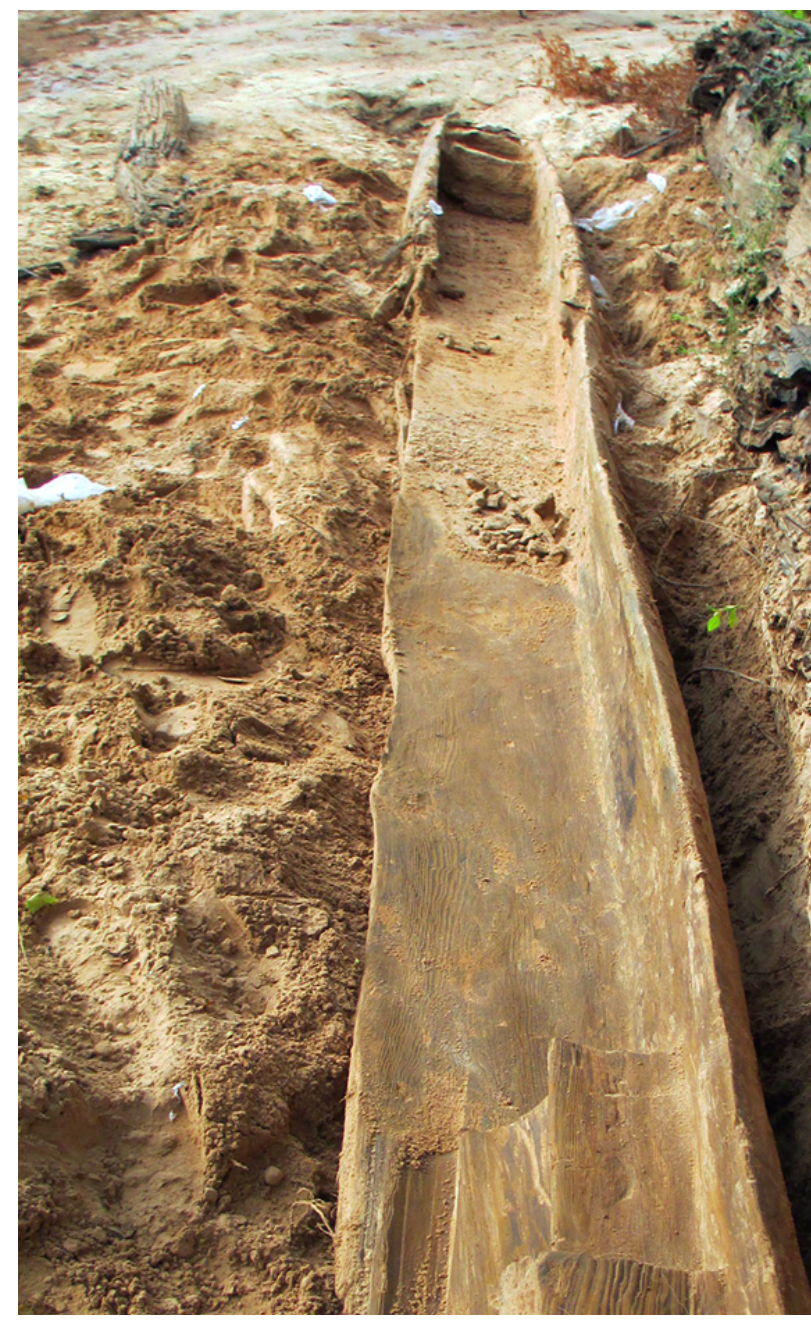

Figure 2. View downslope at the uncovered dugout.
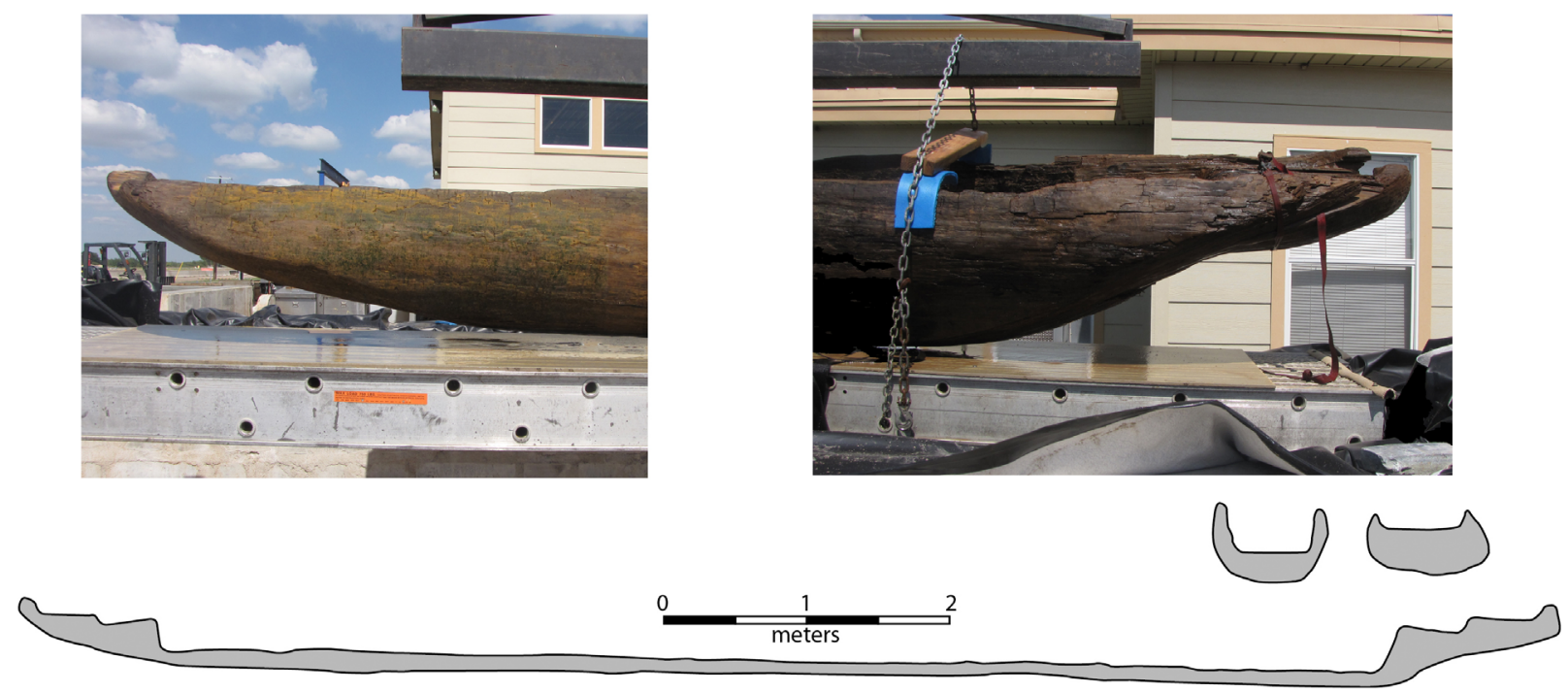

Figure 3. Bow and stern cross sections and profile of the dugout. 
(Figure 6). At the conservation lab, polyethylene glycol (PEG) will be introduced to slowly replace the water in the wood and provide support and stabilization to the structure. Once the PEG has completely impregnated the wood, the canoe will be placed in an enormous freezedryer where, over the course of several months, the water will be drawn out of the wood. A 3-D scan of the canoe will be made as part of the conservation efforts. The entire conservation process is estimated to take three years. Although the exact location has not been determined, plans are underway to return the canoe to Louisiana for public display.
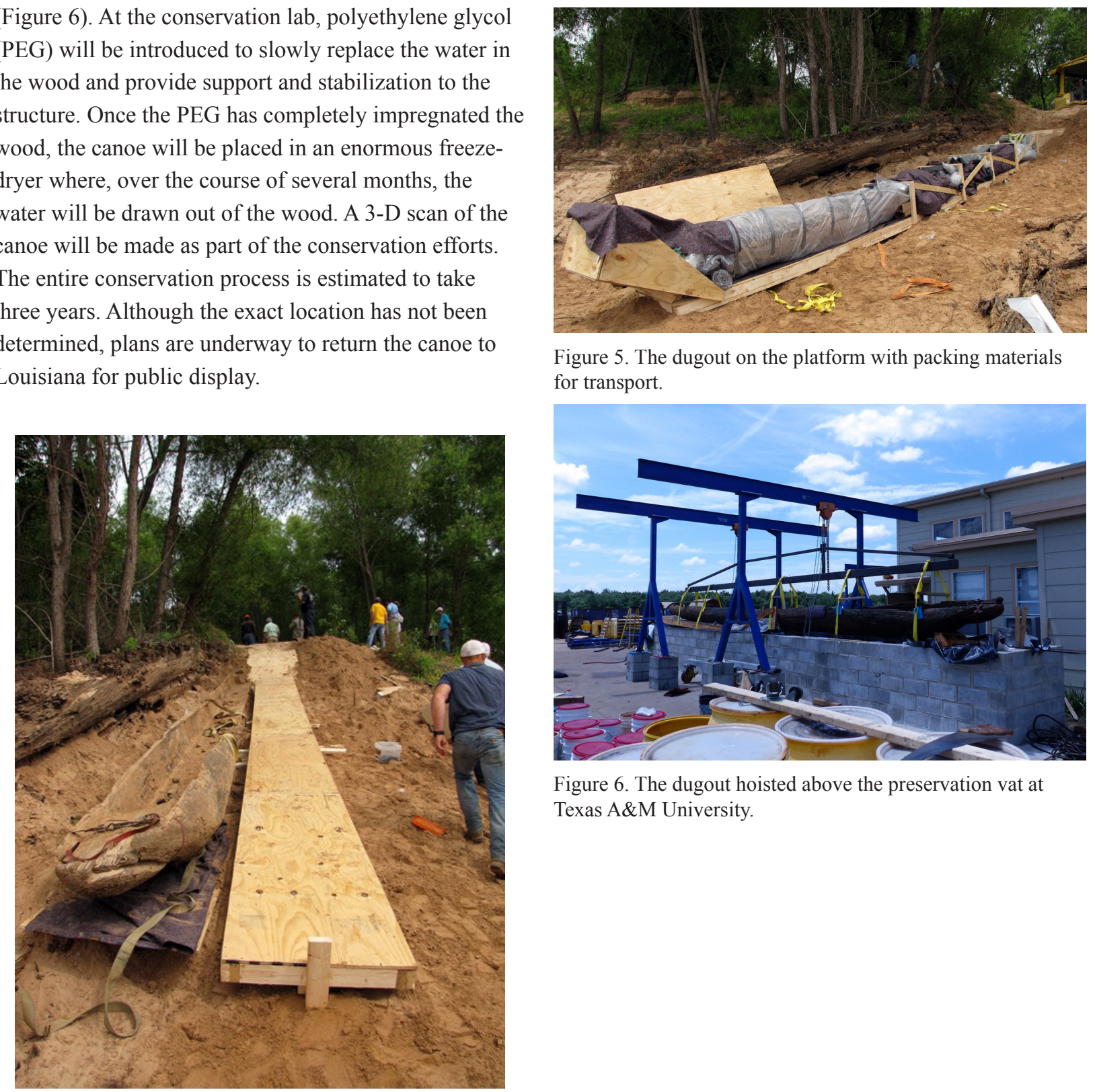

Figure 5. The dugout on the platform with packing materials for transport.

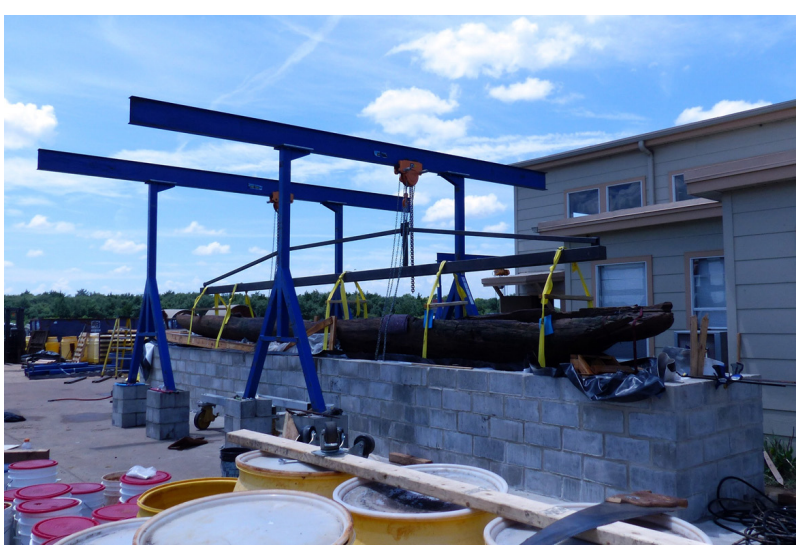

Figure 6. The dugout hoisted above the preservation vat at Texas A\&M University.

Figure 4. Wood platform constructed next to the dugout. 